then made, shows that the southern loop of Herschel's Lemniscate had bulged out into the vacuity, forming an isthmus which trended north and joined the northern loop. The second drawing, January 1870 , shows that within six months this isthmus had detached itself from the north side of the Lemniscate, through $90^{\prime \prime}$, to form a broader peninsula. The third drawing, April 1870 , shows the outline of a gulf or cleft, commencing at $\mathrm{H} 634$. This

PRECEDING

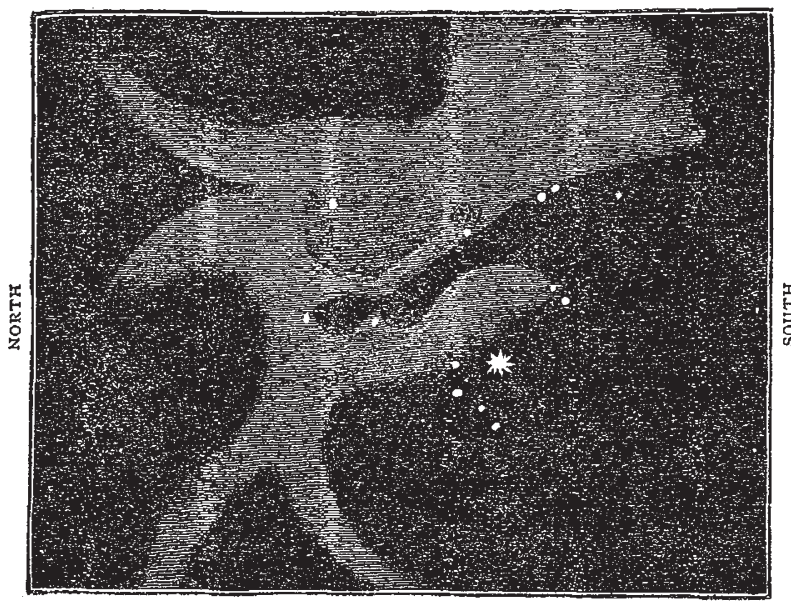

FOLLONING

star is one of the "landmarks" described in 1838 as being "near the margin of the Lemniscate." It is now in midchannel. These three drawings were made by Mr. Le Seur. No. 4 was made by Mr. McGeorge at the close of December in the same year. It confirms the existence of the Gulf ; another of the "landmarks," H 6I6, is now nearly clear of nebula. A promontory shown in No. 2 has detached itself to form an island of nebula with a starry nucleus. This and the neighbouring outline of the Lemniscate have the same hard definite outline given by

PRECEDING

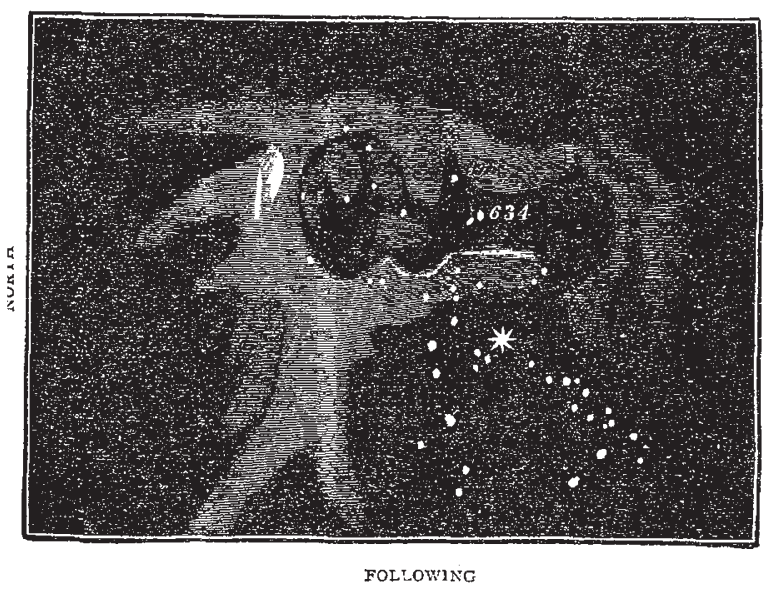

Herschel; at one part, however, the outline seems encroaching upon the Lemniscate, and leaving an oval patch of thinner nebula; southward the outline seems to be curdling and breaking up. A fifth drawing, which is also here given, was made in June $187 \mathrm{r}$, which amongst other changes shows that the island has shifted; the nucleus is now detached from it, and proves to be a triple star.

Mr. McGeorge finds, as Lord Rosse did, that high powers on a good night bring out details of nebula in- visible with lower powers. On one occasion he speaks of using $r, 300$, whose definition, he says, "was magnifi. cent for an hour." He notices a sort of stereoscopic effect which, particularly with the high powers, makes the Lemniscate look "like a huge snowy cave with uncven woolly sides."

In December 1869 the spectrum of $\eta$ Argûs showed bright lines; but in January $187 \mathrm{I}$ there was no trace of them ; but Mr. McGeorge thought that with a wide slit he detected absorption bands in the position of the usual nebular lines. Distinct nebulosity was then visible round the star, most condensed near it, chiefly in the direction of the Lemniscate.

It is perhaps unnecessary to remark that $\mathrm{Mr}$. McGeorge has seen nothing in the way of coloured stars at all to be likened to $\kappa$ Crucis ; one or two are reddish.

It is the intention of the Melbourne astronomers to pursue unremittingly the study of this nebula, which seems already to have given them such remarkable re. sults. But it is evidently a most laborious task which they have imposed on themselves. At present they are confining their attention to the vicinity of the Lemniscate, but even there the field of labour is immense, for already they have noticed three times as many stars as were seen by. Herschel.

They have with them the best wishes and sympathy of all astronomers.

Armagh, April 2I

T. R. ROBINSON

\section{BRITTANY DOLMENS AND LINES}

M R. JAMES FERGUSSON, in his interesting volume on "Rude Stone Monuments in all Countries," which will doubtless become a text-book on that section of archæology which pertains to Megalithic structures, has made one or two unintentional misstatements, discrepancies, or errata, which perhaps he will allow me to correct through your columns, in hopes that they may be in time for the second edition, which is probably called for, if not accomplished. I will state them as briefly as possible.

I. Carnac (p. 349): "No stone in the neighbourhood of Carnac is hewn or even fashioned beyond splitting, and no sculptures of any class have been traced" (italics are mine). Will Mr. Fergusson forgive me if I point out that the tumulus of Kercado, situate in the grounds of the Chateau of the same name, and marked in the map of the neighbourhood of Carnac given in his volume Fig. I 35 as "Kercadio Tums. 2 " has well marked sculpture on at least three of its stones, one of the figures, viz. that on the under-surface of the capstone, being evidently of the same type as the Hatchet (?) in the roof of Dol-auMarchand or Table de César, see Fig. I49 (where by-thebye I never could make out the so-called plume), and is identical with one in Bé-er-groah (Locmariaker). This tumulus, or dolmen-mound, as I prefer to call it, is much nearer to the lines of Kermario and Kerlescant than Mont S. Michel is to the lines of Menec. I should add that M. René Galles figures two of the sculptured stones, but not the hatchet.

But this is not the sole example of sculptured stones in the neighbourhood of the Carnac amorpholiths. In the curiously arranged dolmens called the "Grottes de Kerozille," are distinct traces of former sculpture (in which, if I mistake not, some traces of some coloured pigment have been discovered by W. Lukis), of which M. Galles gives but imperfect representations. Doubtless all the stones were covered with similar ornamentation, which has disappeared from the weathering of the stone surface. The "Grottes de Kerozille" are situate to the north of Menec, about two miles distance, marked Dols. I I and I 2 in MM. Blair and Ronald's map as given by Fergusson. There are in reality three dolmens, the centre one at right 
angles to the other two, and almost connecting them with traces of a fourth; all have been covered under one mound. In "Les Grottes de Plouharnel." where the gold ornaments were found, are traces of rude sculpture. I need hardly add that none of these archaic markings are in relief, as is the case with the celts shown in Sir Henry Dryden's drawing from Gavr' Innis, Fig. 152. Flowing labyrinthical lines seem characteristic of the Kerozille dolmen-mound, whilst straighter lines forming network are peculiar to Kercado. On the summit of the neighbouring dolmen of Runusto are some cup-markings which bear a very fair resemblance to the constellation of the Great Bear together with the Pole Star. The tolmen entrances in the long barrow close to and north of the Kerlescant alignments, one of which is figured (vide Fig. 139), were doubtless fashioned artificially, at least I think Mr. W. Lukis, who has described them, will bear me out in this assertion. It is indeed a monstrous pity that the Société Polymathique du Morbihan should have permitted such an interesting structure to be destroyed.

I should not have taken the trouble of bringing the foregoing notes to the notice of the public in your pages had it not been for the great stress laid by Mr. Fergusson on the fact of the marked distinction made by him between

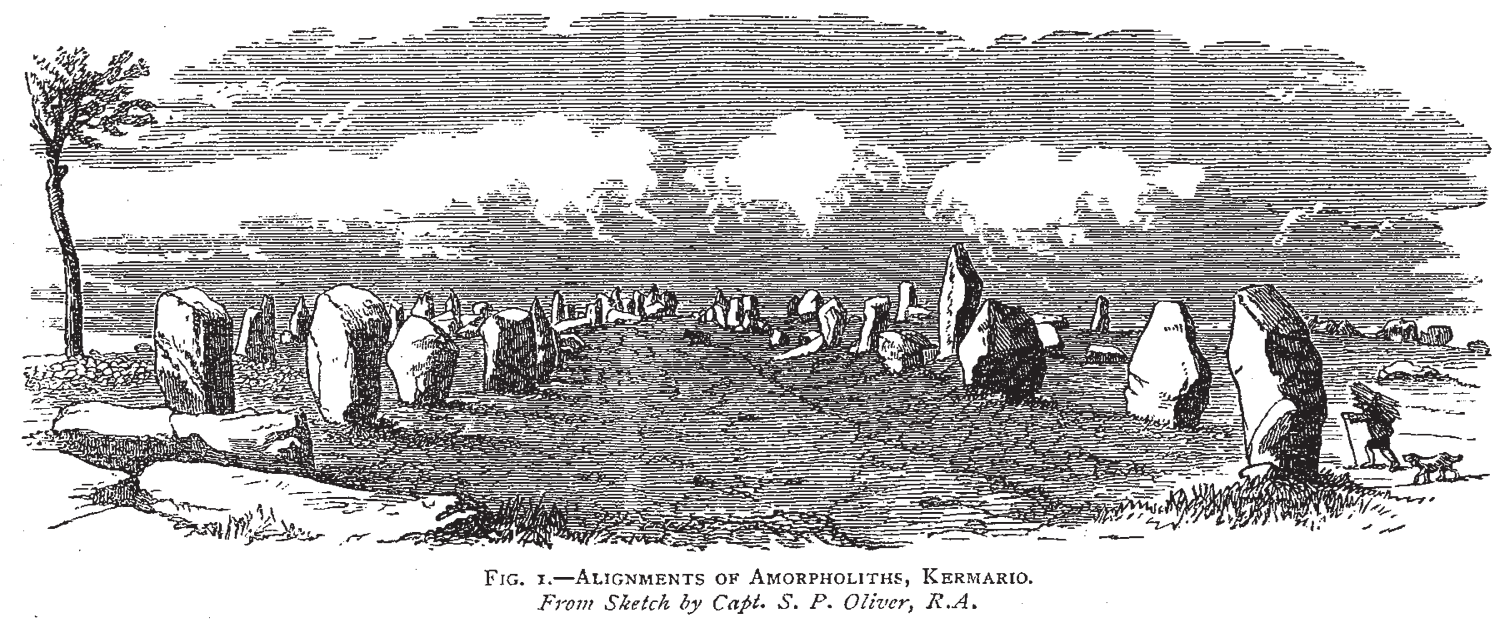

the Locmariaker monuments and those in the neighbourhood of Carnac, the latter of which he asserts cannot be dissociated from the Carnac alignments.

In a communication addressed to the Anthropological Institute, I endeavoured lately,to prove that the hewn and sculptured stones of Locmariaker were of a different type from the rough and shapeless blocks of Carnac, which latter I ventured to distinguish by the name of "Amorpholiths," and for that very reason disassociated the dolmen-mounds, such as Kerlescant, Kercado, and Mont S. Michel, from the lines and avenues, excepting the unchambered barrow at the western extremity of the Kerlescant lines which appear to lead up to it. An endeavour to classify the Dolmen-mounds of Brittany is appended herewith.

II. As to the fallen menhir, which Fergusson asserts belongs to the dolmen named Dol-au-Marchand, and which, in his idea, was in reality two obelisks and not one; the accompanying trustworthy plans and elevation of the renowned monolith ought to prove to the most sceptical that the remains in question are without doubt fragments of one huge monolith, which was, moreover, artificially fashioned, and, possibly, originally actually polished.

I confess that I was disappointed when I found that the Carnac lines were summarily disposed of by Fer-

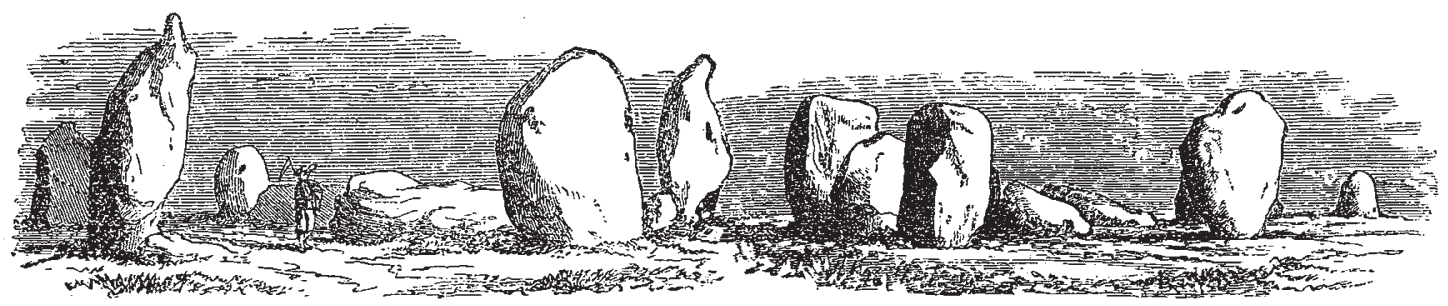

Fig. 2.-Portion of the Kermario Alignments from the Norti. Froin Sketch by Capt. S. P. Oliver, R.A.

gusson in nine pages, whilst over fifty are devoted to Avebury and Stonehenge! (although heterms the former the most remarkable group of megalithic remains, not only in France, but perhapsin the wholeworld); also at not finding a single illustration of the said lines beyond the maps, which, valuable as they are, give no idea to the reader who has not actually visited the spot, of the size and style of the amorpholiths. I enclose a view of the Kermario avenues, looking west, premising that the more distant stones are the largest, and that they decrease in size towards the foreground, the perspective diminishing the effect of this difference in the size of the stones.

III. Why does the celebrated dolmen (Fig. 126) of
Kercouno appear under the name of Krukenho? Louis Galles gives the etymology of this place as "village du souvenir."

IV. Not much faith can be placed in Mahe's (not Malé) representation of an ideal demi-dolmen, Fig. 129. In his "Antiquités du Morbihan," it is ideal, and has no local habitation or name.

V. P. 349. The Veneti are styled Venetes, and p. 356 fibrolite ${ }^{*}$ is printed tribolite-printer's errors! With re-

* La fibrolite est un silicate anhydre d'alumine ; elle doit par ses caractères être rattachée à la sillimanite (des Cloizeaux). Couleur blanc-laiteuse. souvent jaunâtre et marbrée de veines et de tâches grises ou couleur de rouille. A peu près opaque; quelques échantililons monțrent une certaine translucidité. 
gard to this last rare mineral substance, to which Fergusson never alludes beyond mentioning its existence, I pointed out some time since that seventy-five per cent. of the celts found in the sepulchral dolmen-mounds of Brittany were composed of this material.* Can Mr. Fergusson inform us how he accounts for the presence of this substance, as well as the significance of its predominance in association with sepulture? It may be noted that all the fibrolite celts are small and nearly perfect, with sharp edges, and show no signs of use ; whilst the diorite and other celts of a larger type show evident signs of use and are all purposely broken before deposition in the dolmen.

VI. P. 356 . More strictly the jade and turquoise should be termed jadéite and callä̈s, respectively. Mr. Fergusson is right in quoting "jade " and "turquoise" if he goes by M. René Galles' account, and I quoted the same materials myself in an article on Dolmen Mounds in the Quarterly Fournal of Science last January; but these

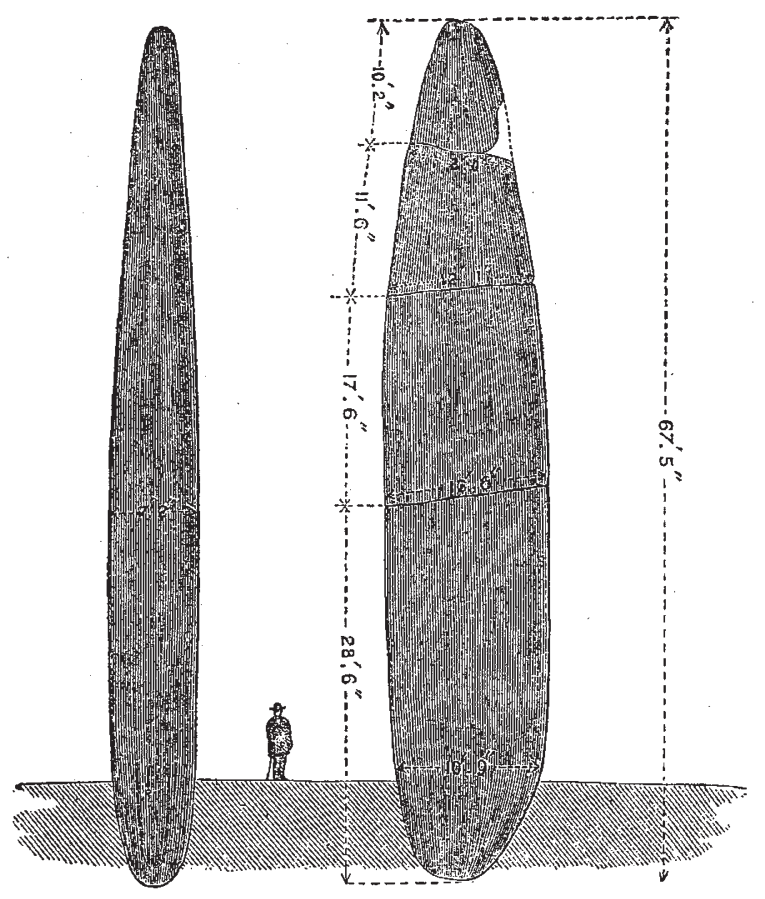

Fig. 3.-Le Grand Menhtr, Restored by Sir Henry Dryden, Bart.; showing its similarity to a Stone Celt.

same articles now in the museum of Vannes are described by the curators Messrs. cie Cussé, L. Galles, and D'Aultdumesnil as jadéite' $\dagger$ and callaïs. ${ }^{\ddagger}$ Structure à fibres fines, soyeuses, très seerées, contournées, et comme entre-
acées en divers sens; ; c'est de là que lui vient son excessive tenacité. Raie acées en divers sens; c'est de là que lui vient son excessive tenacité. Raie e verre et le feldspath, rayée par le quartz. Infusible au chalumeau. Les haches en fibrolite affectent plus ou moins la forme d un parallélogramme allongé, souvent celle d'un trapèze dont la plus grande base offre un tranchant. La fibrolite étant une substance lamelieuse, toutes
de cette matière n'ont qu'une épaisse ur faible et irrégulière.

de cette matièr

* See table. † La jadéite doit être rattachée à la famille des wernérites (silicates anhydres). Couleur de diverses nu ances de vert, de gris verdâtre, de gris jaunâtre, structure cristalline, fihro lamellaire, quelquefais un peu schistoìde, rayant le feldspath et le jade oriental; rayee par le quartz. Très tenace. d'une lampe á alcool, se fond aisément en un verre jaunâtre ou grisâtre, d'une lampe á alcool, se fond aisement en un verre jaunâtre ou grisâtre, demi-transparent.

I La couleur de cette matière est le vert-pomme, se rapprochant du vert de l'émeraude. Quelques échantillons sont comme marbrés de parties blanches et de parties bleuâtres; d'autres sont maculés de veines et de taches brunes ou noires, par suite doun melange accidentel de matieres argileuses. Le est compacte comme celle de la cire. Il raie le calcaire, mais il est facile-
VII. How the barrow north of Kerlescant lines can be said to be related in any way (p. 356) to Mont S. Michel (which is situate south-east of the Menec lines, and at least a mile distant), either in position, size, or structure, I cannot imagine. The former is, or rather was, a long but small structure with fashioned entrances, covered over with a mound which is only visible a few yards off, whilst the latter is an immense tumulus, visible from afar. covering one if not more kists of insignificant structure.

VIII. Mr. Borlase's late discoveries in the dolmenmounds of Trevelgie Head, Cornwall, give additional reasons for supporting Mr. Lukis' theory that both dolmens and cromlechs are merely the skeletons of original chambered tumuli.

IX. P. 389. "Only one drawing of a dolmen in Portugal has as yet, so far as I know, been published."

In $1868 \mathrm{M}$. Da Costa figured twenty Portuguese dolmens, and eight stone implements found in connection with them.*

"In the Peninsula the cromlechs, when denuded, are known under the name of Antas (a term about which there has been much disputing, but which, after all, seems to signify ancient altars used as landmarks) ; those partially enveloped in the tumulus, or on the summit of a mound, are termed Mamunhas (corruption of Mamua or Mamôa-tumulus); and when covered in, as the allées and grottes of Brittany, they are termed Furnas.

"In the year 1734 over three hundred of these remains are mentioned as existing in Portugal, but in $1868 \mathrm{M}$. da Costa could only enumerate forty-two, of which twentyeight are in the province of Aleutejo, twelve in Beira, two in Traz-os-Montes, two in Minho, whilst none remain either in Estramadura or D'Algarve.

"The largest aggregation of these antas appears to be at Contado d'Alcogulo, the property of M. Le Cocq, where there are five remaining together. The only stone implements described by M. da Costa were found here, and consist of half a dozen rude greenstone celts and a quartzite muller. With the exception of four, all the above are denuded and ruined antas; the exceptions are two furnas near Vizella in Minho, the Mamunha de Mamaltar in Beira, and the Mamunha de Carrazedo in Traz-os-Montes. This last is chiefly remarkable from the curious hollow circular mark, presumedly artificial, on one of its supports.

"There is also one curious monument mentioned, as composed of two rows of stones, near a menhir between Cepaes and Fafe, in Minho. As this is the sole description of the monument, and no dimensions are mentioned, it is diffictilt to judge of its composition. It may be analogous to two rows of small vertical stones in the long barrow at Kerlescant, already mentioned, or there may formerly have existed an avenue of stones. Unfortunately it appears that the monument has been destroyed; and the stones made use of in the construction of the neighbouring convent of Pombeiro." +

The above remarks are not written in a carping spirit, but offered merely as additional information to what Sir John Lubbock aptly terms " a rich and trustworthy storehouse of facts," collected with such labour and care by Mr. Fergusson during the last eighteen years.

I will refrain from analysing Mr. Fergusson's theory that the dolmens date from a post-Roman period in the present paper.

ment rayé par une pointe d'acier. Sa poussière est blanche, infusible au chalu meau. Cette substance $\epsilon$ st un phosphate d'alumine hydraté comme la turquoise orientale, mais elle en diffère sensiblement, aussi bien par les iroportions de ses principes constituents que par ses caractères. M. Damour, d'après les différences appréciables qui existent entre ces deux natières, les sépare dans la classification des espèces. Il emprunte à pline le nom de callä̌s, callas, quil applique a notre minéral, et reserve celuillerie.

pierre precieuse de couleur bleu de ciel si connue en joaillerie. Pereira Da Costa. Lisbon, r. 868.

$+V$ "The "The Donuments of Brittany," Part I., by S. P. Oliver, Capt. R.A., Qucterly Fournal of Science, January $187^{2}$ 


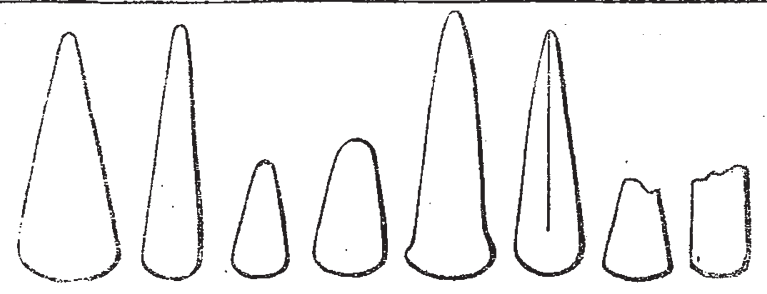

CeltS FROM DOLMEN-MOUNDS IN BRITTANY.

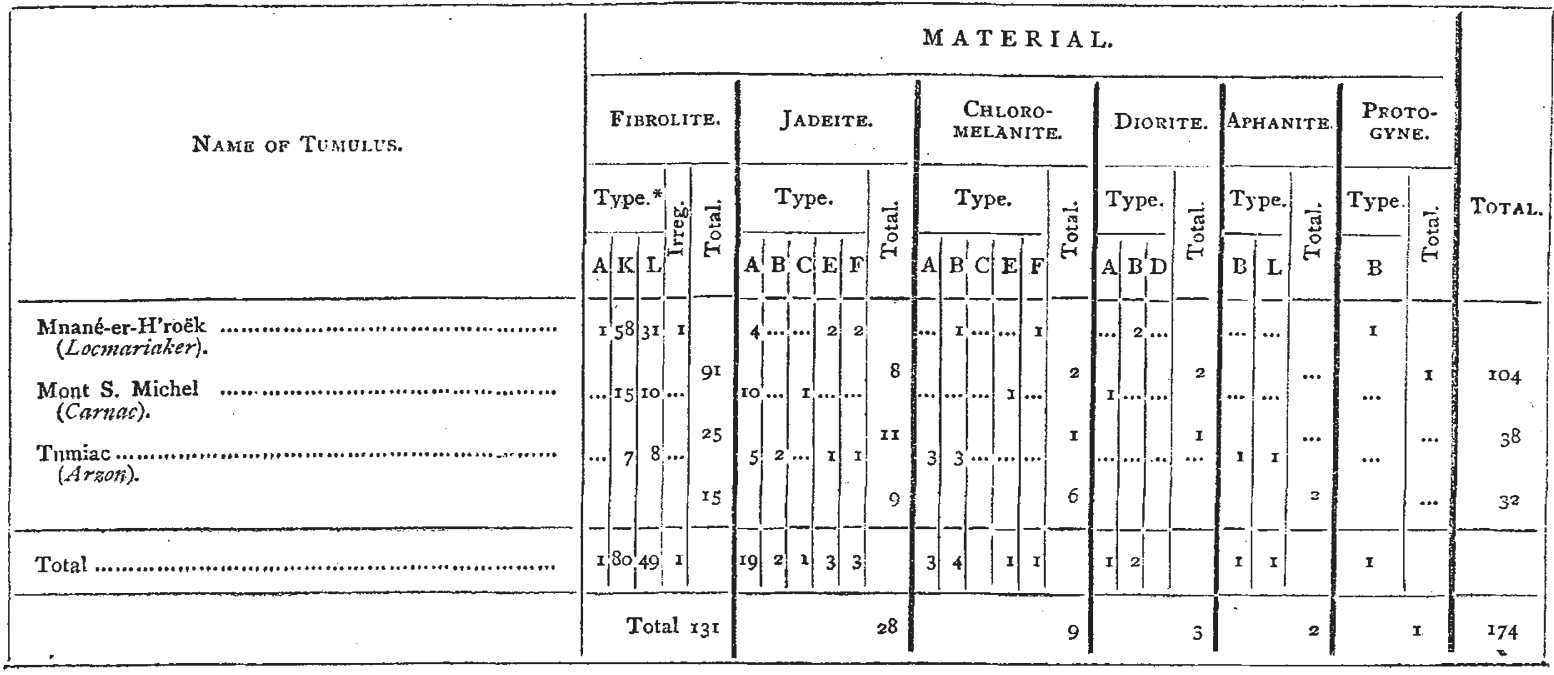

* Types of celts adopted by the Sociéte Polymathique du Morbihan, aud alluded to in the above table.

DOLMEN-MOUNDS OF BRITTANY AND THEIR INTERIOR STRUCTURES

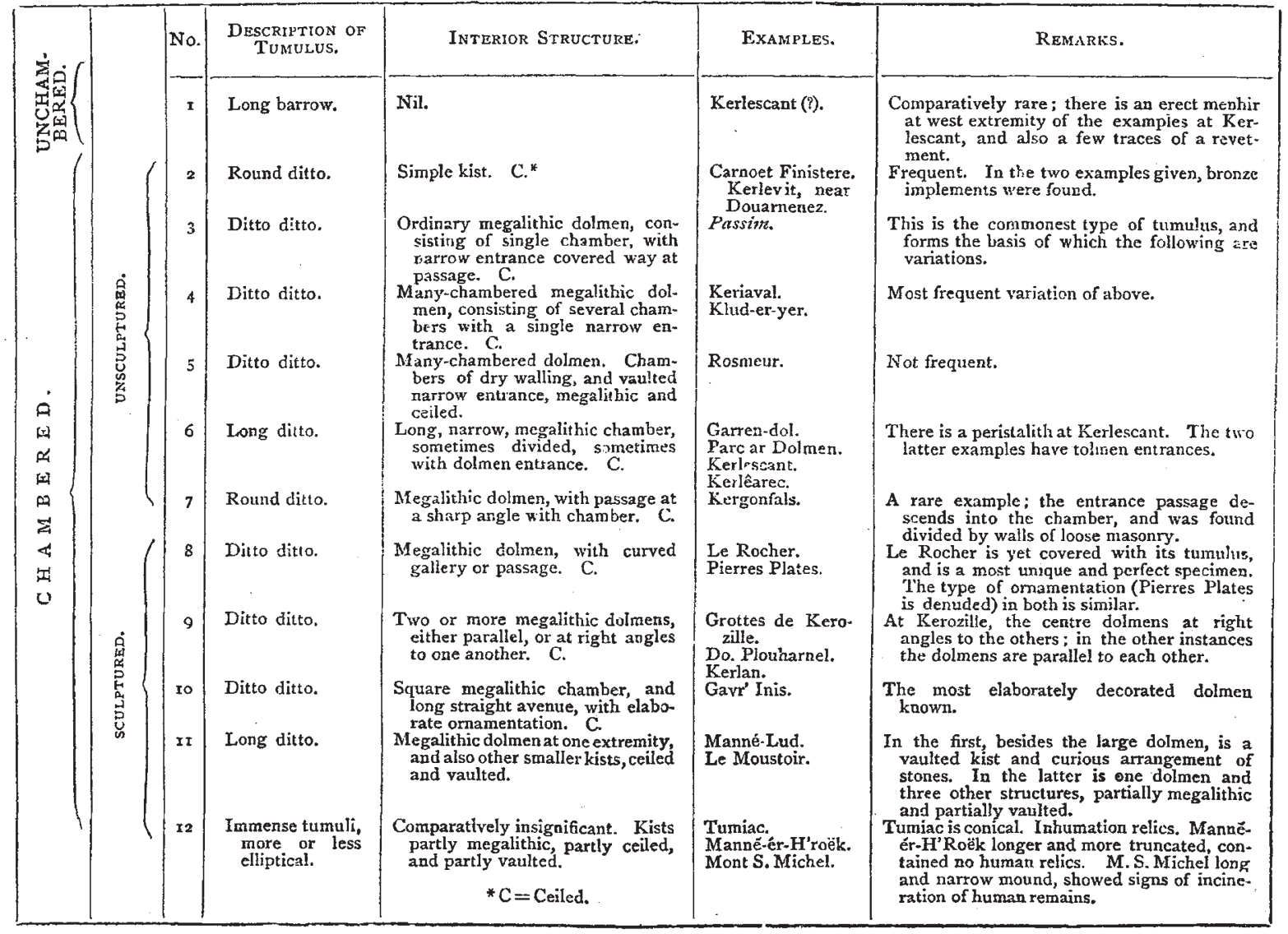

